\title{
ALANA PIPER
}

\section{Victimization Narratives and Courtroom Sexual Politics: Prosecuting Male Burglars and Female Pickpockets in Melbourne, 1860-1921}

$<$ Author info $>$ Research for this article has been supported by the Australian Research Council Laureate Fellowship Program (FL130100050, 2013-18) and the Griffith University Research Infrastructure Program (2014). I would also like to acknowledge the editorial efforts of Dr. Marion Pluskota and Professor Manon van der Heijden in preparing this article for publication, as well as feedback from my colleague Professor Mark Finnane. Address correspondence to Alana Piper, Griffith University, Mt. Gravatt campus, 176 Messines Ridge Rd., Mt. Gravatt, QLD 4122 Australia. Email: a.piper@griffith.edu.au

$<$ Abstract $>$ Abstract

Burglary and pickpocketing were the two most prevalent forms of male and female offending respectively in the flourishing colonial capital of Melbourne during the late nineteenth and early twentieth century. Using court records and newspaper accounts, this article compares the prosecution patterns and public perceptions of male burglars and female pickpockets. Both offences were associated in the Anglophone world with membership of the criminal classes, and in the colonial context with concerns about a remnant convict populace. Moreover, both male burglary and female pickpocketing occurred in intimate contexts that threatened the possibility of sexual violence or uncontrolled female sexuality. Yet although both crimes were the subject of community concerns, the conviction rates for burglary and pickpocketing differed dramatically. This article examines the ways in which the gendered contexts of burglary and pickpocketing - in relation to constructions of victims as much as defendants - exacerbated the usual differences found in trial outcomes for men and women, as well as other factors that served to place men at far greater risk of conviction. It is suggested that a close reading of the victimization narratives of these two offences complicates traditional perspectives on the policing of male and female sexualities in the criminal justice system.

In 1885, 17-year-old Lily Walker alias Miller was tried at the Melbourne Supreme Court for stealing from the person (pickpocketing), the most common indictable crime with which women in the city were charged. Although Walker was a first-time offender, the media described her as a "notorious character," a coded reference to her reputation as a prostitute. ${ }^{1}$ The opportunities to commit theft provided by prostitution were a significant reason for the frequency of this offense among urban female defendants. ${ }^{2}$ Walker's alleged theft followed a typical formula. She waylaid a man on the street by asking him to buy her a drink and offering sex; Walker then robbed him of cash and deposit receipts worth just under $£ 200$. Like many pickpocketing victims, the man was not a Melbourne local, but a farmer just 
arrived in town. As occurred in around 61 percent of cases, Walker avoided conviction

(Table 1). She would repeatedly be acquitted of similar charges over the next 24 years.

\begin{tabular}{|c|c|c|c|}
\hline \multicolumn{4}{|c|}{$\begin{array}{l}\text { Table 1. Female defendants tried Melbourne's Supreme Court and General } \\
\text { Sessions, every year 1860-1920 }\end{array}$} \\
\hline Head charge & $\begin{array}{c}\text { Guilty or partial } \\
\text { guilty verdict or } \\
\text { plea }\end{array}$ & $\begin{array}{l}\text { Not guilty or } \\
\text { prosecution } \\
\text { abandoned }\end{array}$ & Total \\
\hline $\begin{array}{l}\text { Stealing from the } \\
\text { person }\end{array}$ & $213(39 \%)$ & $329(61 \%)$ & 542 \\
\hline Larceny & $114(46 \%)$ & $136(54 \%)$ & 250 \\
\hline $\begin{array}{c}\text { Murder or } \\
\text { manslaughter }\end{array}$ & $69(34 \%)$ & $133(66 \%)$ & 202 \\
\hline $\begin{array}{l}\text { Burglary or breaking } \\
\text { and entering }\end{array}$ & $111(59 \%)$ & $77(41 \%)$ & 188 \\
\hline $\begin{array}{l}\text { Stealing in a } \\
\text { dwelling }\end{array}$ & $118(64 \%)$ & $67(36 \%)$ & 185 \\
\hline Justice offence & $34(30 \%)$ & $78(70 \%)$ & 112 \\
\hline $\begin{array}{c}\text { Non fatal violent } \\
\text { assault }\end{array}$ & $69(64 \%)$ & $39(36 \%)$ & 108 \\
\hline Robbery & $53(58 \%)$ & $39(42 \%)$ & 92 \\
\hline $\begin{array}{l}\text { Fraud, forgery or } \\
\text { false pretences }\end{array}$ & $57(75 \%)$ & $19(25 \%)$ & 76 \\
\hline $\begin{array}{c}\text { Exposing or } \\
\text { abandoning a child }\end{array}$ & $42(58 \%)$ & $30(42 \%)$ & 72 \\
\hline $\begin{array}{l}\text { Miscellaneous } \\
\text { offences }\end{array}$ & $31(45 \%)$ & $38(55 \%)$ & 69 \\
\hline Receiving & $27(43 \%)$ & $35(57 \%)$ & 62 \\
\hline Concealing a birth & $30(54 \%)$ & $26(46 \%)$ & 56 \\
\hline $\begin{array}{c}\text { Arson or property } \\
\text { damage }\end{array}$ & $24(45 \%)$ & $29(55 \%)$ & 53 \\
\hline $\begin{array}{c}\text { Stealing special } \\
\text { circumstances }\end{array}$ & $22(41 \%)$ & $32(59 \%)$ & 54 \\
\hline Bigamy & $39(80 \%)$ & $10(20 \%)$ & 49 \\
\hline $\begin{array}{l}\text { False statement to } \\
\text { registrar }\end{array}$ & $40(93 \%)$ & $3(7 \%)$ & 43 \\
\hline Abortion & $16(41 \%)$ & $23(59 \%)$ & 39 \\
\hline Stealing as a servant & $20(57 \%)$ & $15(43 \%)$ & 35 \\
\hline Total & $1136(50 \%)$ & $1151(50 \%)$ & 2287 \\
\hline
\end{tabular}

William King alias Frazer was less fortunate when he faced his first prosecution three years later. ${ }^{3}$ King was tried at the Melbourne General Sessions for the theft of a watch and chain, valued at $£ 16$, during a home break-in. Burglary or breaking and entering was the most common felonious activity for which men were prosecuted in Melbourne. The 25-year-old 
was convicted, an outcome likely influenced by his racial status as an African-American, as well as by his gender, the crime carrying a conviction rate of approximately 81 percent for male defendants (Table 2). Subsequent convictions meant King spent most of the next three decades in prison. Whereas Walker became well-known in the Melbourne press for her ability to escape conviction, King's criminal celebrity would be built just as much on violent behavior inside prison as on his crimes outside. ${ }^{4}$

\begin{tabular}{|c|c|c|c|}
\hline \multicolumn{4}{|c|}{$\begin{array}{l}\text { Table 2. Male defendants tried Melbourne's Supreme Court and General Sessions, } \\
\text { ten yearly sample 1861-1921 }\end{array}$} \\
\hline Head charge & $\begin{array}{c}\text { Guilty or partial } \\
\text { guilty verdict or } \\
\text { plea }\end{array}$ & $\begin{array}{l}\text { Not guilty or } \\
\text { prosecution } \\
\text { abandoned }\end{array}$ & Total \\
\hline $\begin{array}{l}\text { Burglary or breaking } \\
\text { and entering }\end{array}$ & $417(81 \%)$ & $100(19 \%)$ & 517 \\
\hline Larceny & $194(58 \%)$ & $141(42 \%)$ & 335 \\
\hline $\begin{array}{l}\text { Fraud, forgery or } \\
\text { false pretences }\end{array}$ & $199(73 \%)$ & $72(27 \%)$ & 271 \\
\hline Robbery & $156(37 \%)$ & $156(63 \%)$ & 248 \\
\hline $\begin{array}{c}\text { Non fatal violent } \\
\text { assault }\end{array}$ & $116(58 \%)$ & $85(42 \%)$ & 201 \\
\hline Sexual offence & $117(59 \%)$ & $82(41 \%)$ & 199 \\
\hline $\begin{array}{l}\text { Stealing in a } \\
\text { dwelling }\end{array}$ & $103(74 \%)$ & $37(26 \%)$ & 140 \\
\hline $\begin{array}{l}\text { Stealing from the } \\
\text { person }\end{array}$ & $84(60 \%)$ & $55(40 \%)$ & 139 \\
\hline $\begin{array}{c}\text { Stealing as a servant, } \\
\text { clerk or other } \\
\text { position of trust } \\
\end{array}$ & $86(68 \%)$ & $41(32 \%)$ & 127 \\
\hline $\begin{array}{c}\text { Murder or } \\
\text { manslaughter }\end{array}$ & $39(44 \%)$ & $49(56 \%)$ & 88 \\
\hline Stock stealing & $51(64 \%)$ & $29(36 \%)$ & 80 \\
\hline Justice offence & $27(39 \%)$ & $43(61 \%)$ & 70 \\
\hline Embezzlement & $49(78 \%)$ & $14(22 \%)$ & 63 \\
\hline $\begin{array}{l}\text { Miscellaneous } \\
\text { offences }\end{array}$ & $27(46 \%)$ & $32(54 \%)$ & 59 \\
\hline $\begin{array}{l}\text { Arson/property } \\
\text { damage }\end{array}$ & $22(61 \%)$ & $14(39 \%)$ & 36 \\
\hline $\begin{array}{l}\text { Stealing special } \\
\text { circumstances }\end{array}$ & $14(70 \%)$ & $6(30 \%)$ & 20 \\
\hline Receiving & $8(27 \%)$ & $22(73 \%)$ & 30 \\
\hline Bigamy & $26(90 \%)$ & $3(10 \%)$ & 29 \\
\hline Total & $1735(65 \%)$ & $917(35 \%)$ & 2652 \\
\hline
\end{tabular}


Walker and King thus fared very differently under Victoria's criminal justice system (a descendant of the English court system) as a result of their respective genders. While burglary had one of the highest conviction rates for men of all offenses, for women larceny from the person had one of the lowest (Table 1 and Table 2). In this article, I examine the story behind these numbers by using Walker and King as case studies to scrutinize the different attitudes that male burglary and female pickpocketing roused in the community. In each of these cases, the gender of the accused and the specific offense with which he or she was charged gave rise to a particular victimization narrative that influenced the sexual politics at play in the courtroom. The contrasting experiences of Walker and King thus help illuminate the ways in which sexuality was policed in the courtroom even in property offense cases. They challenge existing conceptions that it was always female sexuality that was more closely scrutinized and harshly judged by the legal system. ${ }^{5}$ While Walker's and King's quasi-celebrity status - along with King's race - meant they were not typical of female pickpockets and male burglars in every respect, their stories are nevertheless representative of significant cultural discourses about these groups in operation during the late nineteenth century.

Why compare two different offense categories? To begin with, the high proportion that male burglary and female pickpocketing constituted of overall offending meant these rates influenced the overall conviction rates for male and female defendants. Explaining the discrepancy between these figures therefore has significance in terms of broader crime trends. The commonalities between the two offenses also make for fertile comparison; apart from their strong associations with particular genders, both were linked to nineteenth-century conceptions of a criminal underworld. They might therefore be expected to have operated as a shared site of community anxiety and, as a result, to have generated similar verdicts and sentences. That these crimes did not in fact yield similar legal outcomes reflects not only the 
gender of the defendants, but also the gendered narratives of victimization associated with each crime category, the different sexual mores associated with them, as well as the extent to which defendants themselves were able to present as victims. Comparison of the two offenses therefore offers an opportunity not only to explore issues of gender, but also sexuality and the history of emotions, themes that have been less common in the historiography of property offenses than that of other offense types.

Studies of gender and crime, particularly in the Australian context, have tended to focus heavily on crimes that explicitly relate to gender dynamics or the sexual economy, such as gender-based violence, abortion, infanticide, baby-farming or prostitution. ${ }^{6}$ Although property crime accounted for the bulk of male and female offending, it has attracted comparatively little attention from gender scholars outside of studies of ostensibly feminine forms of theft, principally shoplifting. ${ }^{7}$ More general studies of crime have naturally observed the different prosecution, conviction and sentencing patterns evident in relation to male and female thieves, but opinions on the causes of these patterns remain divided. ${ }^{8}$

The significance of victim gender has likewise attracted some attention in historical scholarship on crime, though little sustained analysis. In particular it has been recognized that men robbed by female pickpockets often underwent double victimization as a result of the trial process, with Deirdre Palk noting that juries frequently sought to penalize such complainants for "stupidity, drunkenness and lewdness." 9 This has been used to explain why female pickpockets were acquitted more often than male ones; however, as male pickpockets were less likely to be convicted than male burglars, there was also something inherent to the charge itself that either made it more difficult to establish in court, or made it appear less threatening to juries.

Current historiography favors the latter explanation. As J. M. Beattie points out, men accused of burglary were dealt with particularly harshly by the courts because the crime was 
one seen to violate "the privacy and protection of the home and put the inhabitants at risk of being physically assaulted under circumstances in which they could do little to defend themselves." 10 There has been less acknowledgement that this circumstance was perhaps seen as particularly provocative because the inhabitants at risk of violence were often conceived of as women (irrespective of the truth of this representation). Meanwhile, the rare female burglar presumably attracted less ire because her crime was seen to carry less risk of violence - although female burglars were still considerably more likely to be convicted than the more numerous female pickpockets, whose crimes were more likely to involve direct, potentially violent confrontations with their victims. While the focus in this article is on male burglars and female pickpockets, I contend that the reasons why the conviction rates for these offenses differed so drastically from each other is the same as the reasons why they also differed from those of male pickpockets and female burglars: the contexts of victimization were different.

A focused comparison of these two offenses offers an opportunity to re-assess how gender and sexual politics operated in courtrooms. The general historical perspective has been that, as offenders, women fared better in the criminal justice system; they were less likely to be convicted and faced lesser penalties when they were. ${ }^{11}$ As victims of violent and sexual crimes, however, women have been routinely ignored or impugned by incredulous or unsympathetic male officials. ${ }^{12}$ Men meanwhile experienced high conviction rates for property offenses and were targets of a long-term "civilizing mission" with respect to violent offenses, but had their sexuality far less regulated than women. ${ }^{13}$ In particular, the high prosecution rates of women in early modern European jurisdictions has been linked to their being disproportionately affected by the criminalization of moral offenses, ${ }^{14}$ with this double standard persisting in many jurisdictions into the twentieth century as many women but few men were prosecuted in connection to prostitution. ${ }^{15}$ The gendered and sexualized contexts of 
victimization in the crimes discussed in this article complicate such understandings by demonstrating the existence of exceptions in which male sexuality (or the threat of it) damaged men appearing in court in relation to theft cases, while female offenders who contravened prevailing standards of sexual morality enjoyed even greater leniency than other women brought to trial for property offenses.

The data presented is drawn from the court registers of cases scheduled before Melbourne's Supreme Court and General Sessions Court, which together heard all defendants committed for trial on indictable offenses within the greater Melbourne area. ${ }^{16}$ These registers reveal that larceny from the person accounted for 542 of the 2,287 women who appeared before these courts between 1860 and 1920. (Like elsewhere in the Anglo-European world, in nineteenth-century Victoria prosecution rates of women were higher in the urban area.) As a complete dataset of all men tried by the courts is not yet available, a ten-year sample has been drawn from the Australian Prosecution Project database. ${ }^{17}$ This makes use of the same registers as those used to gather the female data. Men's greater rate of offending means a ten-year sample of men arraigned between 1861 and 1921 produces a comparative group of 2,652 defendants, of whom 517 were tried for burglary or breaking and entering offenses. This meant in effect, that while one fifth of male offenders were committing an offense with an extremely high conviction rate, around a quarter of women were committing an offense with an exceptionally low one.

\section{Perceptions of Thieves}

As the most common crimes for men and women respectively, burglary and larceny from the person were to some extent gendered accordingly, which has implications for how the crimes were read by juries. Burglary or breaking and entering was the fourth most common activity for which women were indicted in Melbourne, but they typically only 
constituted around four percent of burglary defendants overall in any given year. Burglary was typically constructed as a skilled, masculine offense. ${ }^{18}$ Furthermore, the trope of the gentleman burglar, popular with the English public at this time, was less prevalent in Australia. ${ }^{19}$ Instead, burglary was associated with a brutish Bill Sykes model of masculinity, ${ }^{20}$ much as street robbery is today. ${ }^{21}$ Women who did commit burglaries were strongly presumed to have been acting under male coercion. ${ }^{22}$ In perhaps a telling illustration of the crime's gender politics, several women who committed burglaries in this period did so while cross-dressing as men. ${ }^{23}$

Pickpocketing was less clearly gendered. Beattie's research suggests that in Surrey in the late eighteenth century, prosecutions of female pickpockets outnumbered those of males by two to one. ${ }^{24}$ Palk likewise found that women continued to exceed men in London's pickpocketing prosecutions into the early nineteenth century, although not to the same extent as in Surrey. ${ }^{25}$ Men predominated in pickpocketing prosecutions in late-nineteenth-century Victoria, but women accounted for an unusually high proportion of defendants. While some contemporaries assumed that women often acted in concert with male "bullies" or pimps in robbing customers, ${ }^{26}$ this is not borne out by court records, which suggest that women were far more likely to pickpocket alone or with other women. ${ }^{27}$ The archetypal male pickpocket meanwhile was usually depicted as an adolescent, or at least a youthful male who affected a dandified appearance in order to pickpocket milling crowds. ${ }^{28}$ As a result, pickpocketing was constructed as a more feminized form of crime than outright robbery or burglary itself.

Whereas London's juvenile underworld has been described as being peopled in the popular imagination by girl prostitutes and boy thieves, ${ }^{29}$ the adult underworld of Melbourne - and other western cities — was depicted as consisting of male burglars and female prostitute-pickpockets. ${ }^{30}$ The association of burglary and pickpocketing with the criminal classes meant concerns about both tended to spike at similar times. At the start of the 
1860 s, there was significant concern about Melbourne's remnant convict population exacerbating crime, in particular burglary and pickpocketing. ${ }^{31}$ Both offenses were also subjects of anxiety in the wake of Victoria's economic depression of the $1890 \mathrm{~s}^{32}$ These changing levels of fear may have had implications for the seriousness of the charges leveled against defendants. In periods of heightened fear, the proportion of women charged with robbery rather than stealing from the person increased, while the proportion of men charged with stealing in a dwelling rather than burglary or breaking and entering generally decreased..$^{33}$

Naturally, not all men accused of burglary or women accused of pickpocketing were professional thieves or prostitutes; several of the female defendants were servants who stole from their masters, while one male burglar was actually a police constable who took advantage of an open window he spotted while patrolling the streets. ${ }^{34}$ However, the initial impression juries would have brought to the courtroom in these cases was that of a potential underworld connection. While the rules of evidence inhibited what could be disclosed about the accused's character at trial, a point in Victoria that rested in particular on a decision taken in a prostitute pickpocketing case in $1870,{ }^{35}$ hints about the accused's status could still be conveyed.

In pickpocketing cases, the circumstances of the crime often linked female defendants to an underclass milieu, an association encouraged by subtle indicators such as residence in a notorious slum or by forthright accounts by the women themselves detailing heavy drinking sessions and sexual activity that left little doubt of their profession. Visual signifiers could also point to women's status. Lily Walker was censoriously described as a "gaudily-attired" female at her hearing in $1885 .{ }^{36}$ Burglars could more easily present themselves as part of a respectable working class. In his later reminiscences, Melbourne police detective David O'Donnell described burglars who deliberately adopted attire and personas in court that 
suggested respectability, even prosperity. ${ }^{37}$ In most cases, there would not be anything in the evidence that necessarily belied these pretensions.

Given the reputed connection of male burglars and female pickpockets to a dangerous underclass, it would be reasonable to expect that the conviction rates for these crimes would be higher than for offenses associated with a better class of offenders. Yet while men accused of burglary were indeed more likely to be convicted than those charged with white-collar crimes (Table 2), women accused of stealing from the person were in fact far less likely to be convicted than those charged with crimes like stealing as a servant (Table 1). The low conviction rate of female pickpockets compared to male burglars is even more perplexing in view of the lack of effect the disclosure of immoral female behavior seems to have had on juries' attitudes, which appears inconsistent with existing arguments positing that women fared best in the justice system when their behavior embodied appropriate models of femininity. ${ }^{38}$ In the following sections, I suggest that the surprising conviction rates for male burglary and female pickpocketing cannot be explained by the class and gender of defendants alone; instead, they reflected how these factors operated in conjunction with narratives of victimization. Basically, the gendered and classed nature of the two crimes, in terms not only of offending but also victimization, meant that burglary elicited a much more fearful reaction. By the early 1900s, Walker's ability to avoid conviction was being reported almost as a running joke. ${ }^{39}$ In contrast, King provoked a more terrified fascination, with a model of him reputedly placed on display in the "chamber of horrors" in Melbourne's Bourke Street waxworks in $1911 . .^{40}$

\section{Perceptions of Victims}

Male burglars prompted greater fear than female pickpockets, and their victims received greater sympathy, because burglary was constructed as a more serious offense. This 
was partly attributable to the increased likelihood that property of greater value would be abstracted from premises than from somebody's person. At least 15 percent of burglary cases involved goods valued at more than 100 pounds, compared to just 2 percent of pickpocketing cases (Table 3). The value of goods was not only higher in burglaries than in pickpocketing cases, but the rate of conviction increased alongside the value of goods across both offense categories. Higher losses meant victims were more likely to experience long-term economic effects. A large burglary of a tobacconist in 1861 resulted in the victim having to sell his property for the benefit of his creditors after being unable to maintain his business. ${ }^{41}$ In contrast, pickpocketing was believed to contribute significantly to the dark figure of crime that went unreported by victims who were willing to accept small losses; this may be one of the reasons that out-of-town visitors, who often carried large amounts of cash on their person, represented a high proportion of pickpocketing prosecutions. ${ }^{42}$

\begin{tabular}{|c|c|c|}
\hline \multicolumn{3}{|c|}{ Table 3. Value of goods stolen by male burglars and female pickpockets } \\
\hline Value of goods & Burglary & Stealing from the person \\
\hline Nothing taken & $23(4 \%)$ & 0 \\
\hline$<5$ pounds & $34(7 \%)$ & $150(28 \%)$ \\
\hline $5-<10$ pounds & $40(8 \%)$ & $104(19 \%)$ \\
\hline $10-<20$ pounds & $30(6 \%)$ & $107(20 \%)$ \\
\hline $20-<30$ pounds & $28(5 \%)$ & $44(8 \%)$ \\
\hline $30-<50$ pounds & $33(6 \%)$ & $36(7 \%)$ \\
\hline $50-<75$ pounds & $18(4 \%)$ & $20(4 \%)$ \\
\hline $75-<100$ pounds & $9(2 \%)$ & $14(3 \%)$ \\
\hline $100-<200$ pounds & $25(5 \%)$ & $1(<1 \%)$ \\
\hline$>200$ pounds & $49(10 \%)$ & $9(2 \%)$ \\
\hline Unknown value & $228(44 \%)$ & $59(11 \%)$ \\
\hline Total & 517 & 542 \\
\hline
\end{tabular}

The greater seriousness attached to burglary also reflected its construction as a more inherently violent crime. This was the result of the gendering of space as much as offenders. The ideology of separate spheres has been used to explain gendered crime patterns, with Beattie theorizing that women's lesser participation in crime was linked to their more limited roles in the public spaces where most crime occurred. ${ }^{43}$ This separate spheres doctrine has 
been challenged in recent years due to increasing recognition that large numbers of women historically remained an active presence in public spaces, just as many men spent a significant proportion of their time in the domestic realm. ${ }^{44}$ However, the point remains that in the public imagination, especially during the nineteenth century, spaces were viewed in gendered terms, and this was likely to affect community attitudes to crime. Burglary was perceived as more egregious partly because it was seen as an attack on private, and therefore feminized, space. By contrast, pickpocketing occurred in the masculinized public realm, where there was a lower expectation of a right to safety and a greater burden on potential victims to be on their guard. ${ }^{45}$

There were also clear differences in assumptions about male and female offenders' capacity for violence. Although pickpocketing was considered a non-violent form of robbery, in practice many cases involved violence by women. Yet assumptions about the ineffectiveness of female violence meant it was often met with amusement rather than fear in courtrooms, with members of the public recorded laughing out loud as victims recounted how women hit them with stones or umbrellas during their attempted escapes. ${ }^{46}$ There was also a greater focus on the sexual rather than violent potential of women's bodies, with minute descriptions of how women came to reach inside men's pockets - usually in the midst of a sexual embrace-likewise prompting humorous outbursts. Conversely, the simple acceptance of men's capacity for violence meant that burglaries were conceived of as engendering violent possibilities, despite the fact that most occurred in the absence of victims.

Within what criminologists refer to as the "hierarchy of victimization," 47 burglary complainants were also likely to be perceived by juries as worthier than pickpocketing complainants due to the comparative backgrounds of the victims themselves. The correlation between pickpocketing and sexual encounters or propositioning meant that men were the victims of an overwhelming 96 percent of female defendants. Burglaries involved a greater 
proportion of female victims, although at 86 percent, men remained the vast majority of complainants (see Table 4). This is unsurprising, given that men comprised the bulk of home and business owners. However, while men were often listed as the official complainant, this hides a significant amount of victimization of female relatives or employees who lost property in burglaries. Witness lists reveal that women appeared as prosecution witnesses in 54 percent of the burglary cases. ${ }^{48}$ In some trials, these women actually provided the main evidence in the case, either because they had been at home while the theft took place, or were in a better position to identify the goods taken. ${ }^{49}$ Perhaps due to assumptions about the unreliability of women as witnesses, juries were slightly more likely to acquit in burglaries involving female victims or witnesses, although interestingly defendants themselves were more likely to plead guilty in such cases. In contrast, the construction of women as more vulnerable, and therefore as more "natural victims," ${ }^{50}$ had a more expected effect in pickpocketing cases, increasing the chance of conviction to 45 percent (against 39 percent with male victims).

\begin{tabular}{|c|c|c|c|}
\hline \multicolumn{4}{|c|}{ Table 4. Conviction rates by sex of victims } \\
\hline $\begin{array}{c}\text { Victim sex by } \\
\text { offence }\end{array}$ & $\begin{array}{c}\text { Guilty or partial } \\
\text { guilty verdict or } \\
\text { plea }\end{array}$ & $\begin{array}{c}\text { Not guilty or } \\
\text { prosecution } \\
\text { abandoned }\end{array}$ & Total \\
\hline $\begin{array}{c}\text { Male victims, } \\
\text { burglary }\end{array}$ & $361(81 \%)$ & $84(19 \%)$ & 445 \\
\hline $\begin{array}{c}\text { Female victims, } \\
\text { burglary }\end{array}$ & $56(78 \%)$ & $16(12 \%)$ & 72 \\
\hline $\begin{array}{c}\text { Male victims, stealing } \\
\text { from the person }\end{array}$ & $203(39 \%)$ & $317(61 \%)$ & 520 \\
\hline $\begin{array}{c}\text { Female victims, } \\
\text { stealing from the } \\
\text { person }\end{array}$ & $10(45 \%)$ & $12(55 \%)$ & 22 \\
\hline
\end{tabular}

The class of victims operated on the outcomes of both crimes in more predictable ways. Complainants in pickpocketing cases were predominantly working class, mainly miners, sailors or laborers. In contrast, burglary encompassed a more diverse range of occupations, and contained a higher proportion of victims from the business or professional 
classes. Some notably involved victims known to defendants, but above them on the social scale, such as employers, or, in a few instances, charity workers from whom they had received support. $^{51}$

The different class status of the two sets of victims is also evident from the localities where the crimes occurred. Pickpocketing cases overwhelmingly emanated from the inner city, with a small proportion in the immediately surrounding neighborhoods, and hardly any at all in the more affluent outer suburbs. In burglaries, this pattern was reversed, although the overall distribution was less uneven than in pickpocketing cases. Burglary was thus more threatening not only because it was more likely to affect the propertied classes, but because it was less discriminating in general. As Eloise Moss points out in a recent study of burglary in England, there was a growing discourse from the 1890s that anyone could fall victim to burglary, propagated in part by the rise of insurance companies. ${ }^{52}$ Meanwhile, the concentration of pickpocketing into known danger zones, and into particular locations within these such as hotels, back-alleys or brothels, meant victimization within these spaces was seen as more predictable, and the men involved more responsible for their own victimization. $^{53}$

\section{Victim Blaming}

As various crime historians have observed, the strength of the association between female pickpocketing and prostitution meant that many men were reluctant to initiate prosecutions for fear of the publicity a trial would attract. ${ }^{54}$ This may be another reason for the high proportion of trials involving strangers to Melbourne and men from the lower classes. Women even used the threat of scandal to blackmail victims into not filing complaints. When James Manley was handing his two female assailants over to police in 1915 , one threatened that if he went through with it she would "swear all kinds of lies 
imaginable" in court against him and pay the sensationalist tabloid Truth to have him "exposed." 55 In the face of such threats, some men attempted to halt the prosecution instigated on their behalf. ${ }^{56}$ Other cases were dropped after victims failed to appear to give evidence. ${ }^{57}$ As a result of such non-appearance of witnesses or other case weaknesses, prosecution was abandoned against 70 of the 542 women tried for stealing from the person (nearly 13 percent), compared to only 29 of the 517 men tried for burglary (less than 6 percent).

Victims were right to assume they would receive little sympathy. Newspapers typically reported pickpocketing cases in derisive terms, one paper describing a case in 1883 as "the old, old story" of a "fool and his money." 58 Another reported the theft of a miner's money by two women under the heading "A Stupid Digger." 59 Some officials took a similar view. Following the 1874 trial of two women for robbing a man in a brothel, Melbourne Gaol Superintendent John Castieau noted that while there was "no doubt" of their guilt, they were acquitted after the judge, who "seemed to think it served the loser right," summed up in the prisoners' favor. ${ }^{60}$ At the conclusion of another case in 1902, Judge Hamilton likewise declared that "people who went about at that hour of night accosting strange women should not complain if the end of their adventures was not as happy as they had expected." ${ }^{61}$ Juries appear to have shared such attitudes, resulting in some clear cases of jury nullification. ${ }^{62}$ Even when juries did convict, they sometimes recommended mercy on the grounds of "the great temptation" to which the female culprits had been exposed. ${ }^{63}$

Such attitudes offer a different perspective on the comparative policing of male and female sexuality than that provided by accounts of other crimes, suggesting that in some circumstances men were held to a higher level of accountability for using prostitutes than women were for being ones. Moreover, in line with the findings of contemporary criminological studies of street robbery, complainants in cases of female pickpocketing were 
subject to the same type of victim blaming as complainants in rape cases. ${ }^{64}$ During crossexamination, pickpocketing victims were questioned minutely about their reasons for being out on the night in question and about any sexual activity that had occurred. This could taint perceptions of victims even when men denied that they had been with women for an immoral purpose. How much they had to drink was also a frequent topic of questioning, with allegations of victim intoxication in at least 40 percent of cases. The commentary in such instances suggests that the implication that men had been drunk not only called into question their identification of defendants, but further lessened their status as deserving victims.

Reluctant complainants and juries more incensed by immorality than crime were blamed for the majority of acquittals against Lily Walker. In 1908, however, it seems that Walker had finally gone too far when, in the company of a woman named May Pearson, she pickpocketed clergyman Reverend William Barrie. Barrie had been staying with family at the Federal Palace Hotel. According to Barrie's version of events, upon finding there were no matches in his room late one night, he went outside to purchase some. Having bought several boxes from a street seller, he was about to re-enter the hotel when two women accosted him. He attempted to walk on, but they jostled him into an alley where Pearson allegedly threw her arms around him while Walker abstracted his purse. Walker then ran away; Barrie managed to hold on to Pearson while shouting for police. Walker was quickly apprehended, but the money was not found on either her or Pearson.

The assault against Barrie was reported by the Age as an "amazing outrage." 65 The paper was quick to label the attack as part of an "epidemic of unbridled lawlessness in the streets on the part of persons who seem to have no fear whatever of consequences." 66 The victimization of a clergyman may have created resentment even within the rough workingclass community in which Walker moved. On 7 February 1909, Walker was brought to the police court on offensive behavior charges along with May Pearson and a man named John 
Black. The evidence suggests that Black had angrily confronted Pearson in Collins Street, most likely about the assault on Barrie. Whatever the subject of their conversation, it had caused Pearson to then turn and point to Walker across the street, calling out "There's the woman who robbed the parson." Black then crossed the street and began to yell at Walker, eventually striking her before the intervention of police. ${ }^{67}$ In victimizing a "parson", it seems Walker may finally have exceeded community tolerance.

At trial, however, Barrie's identification of the women, and his reasons for being out late at night, were called into question. As a result of these tactics, the jury failed to agree on a verdict. At the subsequent retrial, the prosecution pointed out that the nature of the evidence, which basically pitted Barrie's testimony against that of the women, meant the clergyman himself was "practically on his trial, and that a slur would be cast against him if the women acquitted." ${ }^{\prime 68}$ The cross-examination of Barrie mirrored the preoccupations of rape trials, with questions about his level of resistance and insinuations of sexual misconduct:

You offered a stout resistance? - Yes. I called out 'Police.' I kept shouting it out. - And how long were you, a poor mere man, in the hands of this vigorous female? - For a minute or so. She did nothing but clasp me in her arms. (Laughter.) What for? - To take my money, of course. ${ }^{69}$

After a lengthy deliberation, during which the jury returned to court to further question Barrie, a guilty verdict was returned against both Walker and Pearson. To the end Walker implied Barrie was at fault, proclaiming as she was taken from court "God will judge me and also you, Mr Barrie."70

Victim blaming was rarer in burglary cases. When it was invoked, it was usually in reference to the failure of complainants to properly secure their premises. In one 1871 trial, for instance, the Judge announced his intention to give a more lenient sentence than in other burglary cases, as the victim had left his window open, and "so tempted persons to enter.""71 The lack of moral censorship attached to such victim blaming meant they were less likely to 
result in outright acquittals. An exception occurred in one case, in which the defendant refuted the charges by attacking the sexual history of the main witness against him. In 1901 maid Becky Douglas found William Argall unlawfully on her employer's premises and, with the help of another woman, chased him outside. Argall was then found to be in possession of various items stolen from the house. Argall's defense was that he had gone to the residence at Douglas's invitation, having been in a sexual relationship with her for several months, and had stolen the items found on him while in a state of senseless intoxication. While Douglas's employer vouched for her respectability, Argall produced witnesses from the neighbourhood who claimed Douglas was well-known as a promiscuous character, a young bootmaker declaring that the local youths referred to her as "the small paddock with the big gate." "72 Two juries failed to agree on Argall's guilt, and at his third trial he was acquitted.

Mostly, however, when issues of sexuality were raised in burglary trials, it served to make victims more sympathetic and men more culpable. The potential scenario of men invading the home while women, and sometimes only women, were present, meant there was an association between burglary and sexual violence. Across the period, several notorious rapes took place during burglaries. ${ }^{73}$ The robbery-rape scenario was in fact the type of sexual violence most likely to be accorded sympathy and accepted as genuine, the unlawful taking of property serving as powerful corroboration of women's lack of consent and men's criminal intent. ${ }^{74}$ Female vulnerability was often emphasized in media accounts of burglaries even when sexual violence did not feature in the case. Details dwelt on included burglars sneaking into rooms where women lay in bed, or women having been only 'partially dressed' during the theft. ${ }^{75}$ Where such intimations occurred, a severe view of the case was usually taken. It is 
noticeable that the three men sentenced to death for burglary in the sample had all victimized women. ${ }^{76}$

William King's infamy was bolstered by the fact several of his victims were women. One burglary in 1900 attracted particular attention due to the crime's sexual overtones. The offense, committed less than a month after King's most recent exit from jail, took place in the prosperous suburb of Prahran. The teenage daughter of the house awoke to find a man in her room in the act of stealing a watch. He then made several sexual threats before fleeing. It was this "combination of offenses" that reputedly convinced the "whole of the police and detective forces" that King was the guilty party, even though neither the girl nor anyone else had been able to identify him as the intruder. ${ }^{77}$ When evidence was discovered linking King to the crime, it also reinforced the perception of King's dangerous sexuality, as King had given jewelry from the burglary to two women. The media implied that King was thus using his robberies to coerce white women into conducting sexual liaisons with him, although it seems from their depositions that he simply employed them to fence goods on his behalf. ${ }^{78}$

In later years the sexual aspects of King's crimes seem to have overshadowed the fact that he was only ever convicted in relation to property offenses. In 1909, the Argus misleadingly reported that "King's first notorious crime was that in which he committed an offense upon a young girl at Prahran."79 The previous year, King had been convicted of two more burglaries involving female victims, the media dwelling in particular on the terror one woman described experiencing upon finding a 'black' in her house at night. ${ }^{80}$

The sexualized construction of King's actions was undoubtedly due in part to his racial background. In his memoir police detective David O'Donnell recalled King's case at length, introducing him in the following terms:

About 1887 or 1888, a big, burly, repulsive looking American nigger, named William King, who was said to be a run-away sailor, made his presence felt in Melbourne and suburbs, by committing a series of daring burglaries....At first, 
he received short, sharp sentences, but as that did not cure his propensity for midnight marauding and as his crimes became more and more serious and absolutely dangerous to life and limb and especially to the life and limbs of women, the length of his sentences had to be considerably increased...

O’Donnell also described King in animalistic terms "roving over the city and suburbs like a wild beast," and cited him as evidence supporting the race-based theories of sexologist Richard von Kraft-Ebing and criminal anthropologist Havelock Ellis. ${ }^{81}$

The presence of an African-American diaspora in nineteenth-century Australia had largely been forgotten until recently. Cassandra Pybus suggests that the historic use of the generic term "black" to describe a variety of persons of color meant such individuals were later assumed to be Aboriginal. ${ }^{82}$ It seems likely that men of African origins suffered similar inequalities under the criminal justice system to those experienced by Aborigines, although the latter group were predominantly tried for homicides or livestock theft. ${ }^{83}$ The precise number of African Americans processed by the justice system is difficult to determine as they were not recognized as a separate category within official crime statistics.

However, it is clear that William King was far from the only man of color whose illegal activities attracted undue attention in Melbourne in this period. Walker herself was arrested alongside "coloured seaman" George Hall in 1886, after Hall apparently used the pay from his latest voyage to set up Walker and another prostitute in their own brothel. ${ }^{84}$ They had only been in residence a few days when Hall was charged with brothel-keeping and the women with vagrancy. Given that the brothel was established in an alleyway off Little Lonsdale Street, an area that contained many similar ventures, the speed with which Hall was prosecuted suggests the house probably attracted attention not because it was being used for prostitution, but because an African American was residing there with two white women. Another "coloured man," Joseph Williams, likewise elicited particular notice in the media in 1911 after he was accused not just of burglarizing, but of "terrorizing" a woman living alone 
with her six children while her husband was working elsewhere. ${ }^{85}$ A sentence of death was recorded against him, but this was later commuted to ten years hard labor.

Yet while race influenced sexualized constructions of crimes, representations of burglaries in general tended to use the victimization of women to emphasize the crime's heinousness. This is evident not only in the media's written accounts, but their visual imagery. For instance, women featured prominently in the sketches of burglaries that appeared in the Melbourne serial Police News. One from 1876 showed "two heroic ladies" trying to repel a pair of "midnight marauders"; above it was a more conventional image of a woman cowering behind her husband as he shot at a burglar. ${ }^{86}$ A particularly suggestive image appeared the following year that depicted a woman bound and gagged against a post while four masked burglars, ignoring the collected loot placed in front of them, stare intently in her direction (Figure 1). ${ }^{87}$ Such ominous imagery intimates that burglaries raised concerns not only about the risk of serious economic losses, but also about possible physical and sexual violence. As a result, men like King were seen as the quintessential criminals, literally and figuratively a race apart, with no respect for person or property.

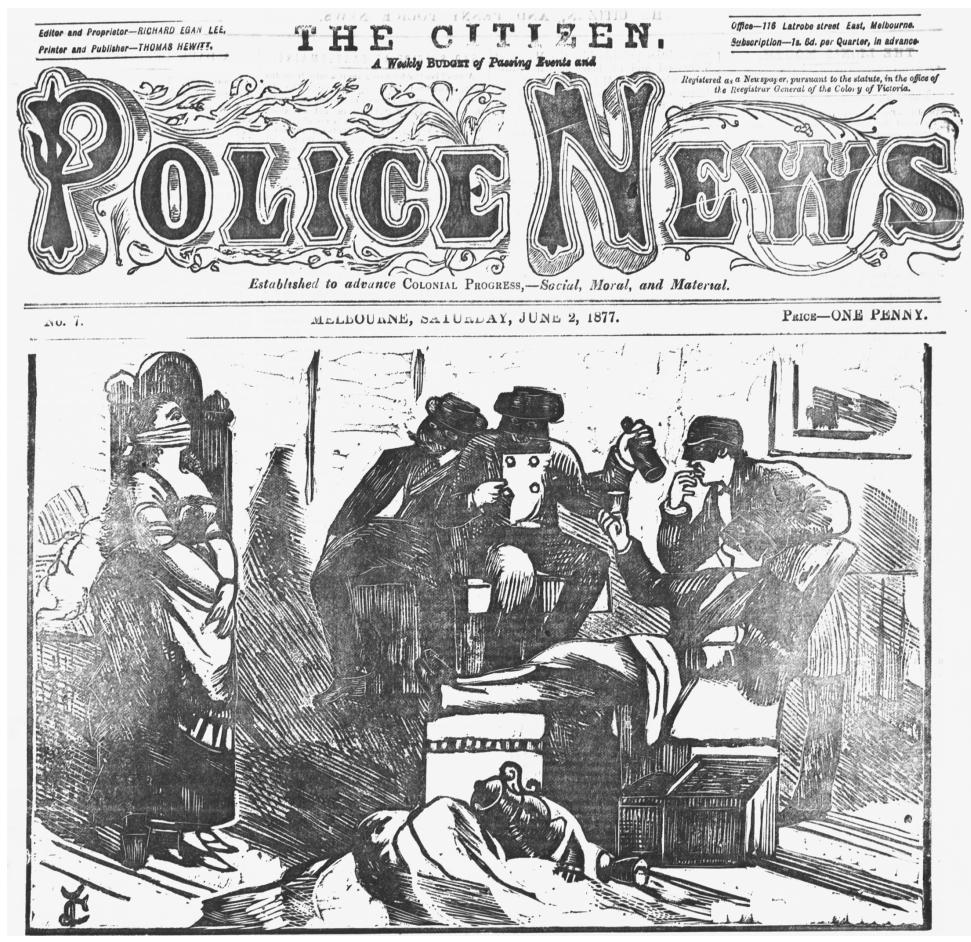

Figure 1. Cartoon of burglary. Police News (Melbourne), 2 June 1877, 1. 


\section{From Thieves to Victims}

While victimization narratives thus often constructed burglars as particularly monstrous, many prostitutes, despite the subversive nature of their activities, were able to reposition themselves as the victims in cases of larceny from the person. A number of women claimed that stolen money or watches had actually been given to them in payment for their services, but that after the transaction the men had tried to reclaim their property by force or by threatening to bring charges. ${ }^{88}$ As men traditionally used their watches as pledges of payment to prostitutes, there may have been some basis for the women's claims. ${ }^{89}$ It is further true that, then as now, perpetrators of crimes were often also victims of them. ${ }^{90}$ Walker herself was a robbery victim in 1889 and again the following year. In both cases the men accused were acquitted. ${ }^{91}$ However, other thefts in which prostitutes figured as victims did result in convictions. When William Orrell was thus convicted in 1887, the judge announced that he would not implement the jury's recommendation of mercy, as he wished to pass a sentence "which would show that girls of the town would receive the protection of the law, and that their property was not to be stolen by men who choose to consort with them." 92 The judge added that he considered that Orrell had compounded his guilt by the "base act" of falsely charging the girl with stealing his watch. Judges and juries might therefore have been ready to believe female defendants' claims of victimization.

Burglars did not figure as victims of crime to the extent that female pickpockets did, though in 1891 one did claim that he was unable to return the stolen property because he had been burgled himself. ${ }^{93}$ Occasionally men tried to shift blame to their victims by claiming a legitimate right to the property in question. However, to gain jury or judicial sympathy, most male burglars represented themselves as victims not of individuals, but of wider social forces. 
Whereas alcohol use was raised in pickpocketing cases as an issue of victim credibility, in burglary cases it was the defendant's drinking that was cited as a factor lessening their criminal responsibility. ${ }^{94}$

Burglars also commonly claimed to be victims of police corruption. William King complained of police harassment at his sentencing hearing in 1900, asserting that the police had hampered his attempts to seek work by shadowing him after his release from prison, then brought charges against him even though they had never been able to catch him "doing anything wrong." $" 95$ At his 1908 trial, King argued that he was also a victim of racial profiling, declaring "I am not to answer for the crimes of all the black men in Australia." ${ }^{\text {" S6 }}$ Some accused did not abandon their claims of police malfeasance even after the trial's conclusion. A diary kept by burglar George Edwards while imprisoned at the Melbourne Gaol in the 1870s was largely an attempt to explain in detail the way he had been framed by police. ${ }^{97}$ However, whereas as the characters of male complainants in female pickpocketing cases seem to have been fairly easy to impeach, the higher regard with which police were held meant burglars' claims to have been victims of police malfeasance was not particularly successful as a defense strategy.

\begin{tabular}{|c|c|c|c|}
\hline \multicolumn{4}{|c|}{ Table 5. Conviction rates by legal representation status } \\
\hline $\begin{array}{c}\text { Legal representation } \\
\text { status by offence }\end{array}$ & $\begin{array}{c}\text { Guilty or partial } \\
\text { guilty verdict or } \\
\text { plea }\end{array}$ & $\begin{array}{c}\text { Not guilty or } \\
\text { prosecution } \\
\text { abandoned }\end{array}$ & Total \\
\hline Defended (burglary) & $90(69 \%)$ & $40(31 \%)$ & 130 \\
\hline Undefended (burglary) & $152(94.4 \%)$ & $9(5.6 \%)$ & 161 \\
\hline Unknown (burglary) & $175(77.4 \%)$ & $51(22.6 \%)$ & 226 \\
\hline $\begin{array}{c}\text { Defended (stealing } \\
\text { from the person) }\end{array}$ & $73(33 \%)$ & $146(67 \%)$ & 219 \\
\hline $\begin{array}{c}\text { Undefended (stealing } \\
\text { from the person) }\end{array}$ & $51(58 \%)$ & $37(42 \%)$ & 88 \\
\hline $\begin{array}{c}\text { Unknown (stealing } \\
\text { from the person) }\end{array}$ & $89(38 \%)$ & $146(62 \%)$ & 235 \\
\hline
\end{tabular}

The greater success women enjoyed in recasting victimization narratives was likely also related to the fact that they were more likely to have lawyers to implement this defense 
tactic. Using court records and newspaper reports, information on whether defendants had legal representation was ascertained for 56 percent of women accused of pickpocketing. Of these, 71 percent were defended, and 29 percent were undefended. In contrast, of the 57 percent of cases where such details could be ascertained for men charged with burglary or breaking and entering, 55 percent were defended and 45 percent were undefended (Table 5). By the 1890 s, women appear to have been more likely than men to have legal representation in general. State-sponsored legal aid was only available in a very limited form in Victoria during this period, but women may have been greater recipients of charitable or subsidized legal assistance. ${ }^{98}$ The high rate of representation among female pickpockets perhaps also presents tangible support for anecdotal evidence that prostitutes would club together to pay each other's various legal expenses. ${ }^{99}$

There was a strong positive correlation between legal representation and acquittal rates. Of defended women, 33 percent were convicted, compared to 58 percent of undefended women. Being defended did not eliminate the gender bias in conviction trends for men, but it did substantially improve these defendants' odds: Whereas 69 percent of male burglars with legal representation were convicted, the conviction rate of undefended male burglars was 95 percent. Walker obviously thought a lawyer's fee was money well spent, employing a solicitor even when charged with the minor offenses of vagrancy and obscene language in $1886 .{ }^{100}$

King, meanwhile, was undefended at his various burglary hearings. At his trial in 1900 , King asked the judge to lodge an appeal on the grounds that he had been "thrown over" by his lawyer and been unable to secure defense witnesses. The judge refused. ${ }^{101}$ King made an attempt to defend himself during his trials, but his efforts obviously were unsuccessful. Newspaper reports often described unrepresented burglars making "rambling" statements in their own defense, suggesting their attempted explanations largely fell on deaf ears. ${ }^{102}$ The 
fears expressed in the early nineteenth century that the introduction of defense counsel would lead to an unequal distribution of justice based on the ability of defendants to secure legal help thus appears to have been borne out. This inequality operated not only across lines of class, but also gender. ${ }^{103}$

\section{Changing Punitive Responses}

Some officials grew weary of the repeated failure of juries to convict women charged with larceny from the person. In January 1903, Walker was again brought up on pickpocketing charges before the Court of Petty Sessions (which committed those charged with indictable crimes for trial in the higher courts). Magistrate Panton wearily declared, "We have frequently sent up Lily Walker for trial with a knowledge that the case is pretty clear against her. It however, appears to be of very little use, but it is our intention to persevere."104 When Walker reappeared before Panton again six months later, she had not only beat the January prosecution, but had been acquitted of another just a week before. The magistrate remarked that the situation was especially dangerous because there were probably hundreds of crimes committed in Melbourne by women like Walker that never even made it to court. ${ }^{105}$ When convictions were secured, judges sometimes took the opportunity to inflict punishments that they hoped would serve as salutary lessons to others. At the trial of 26-yearold woman in 1909, her lawyer pleaded for her to be dealt with leniently on the grounds that she had never been to gaol before, and imprisonment was only likely to worsen her. The judge responded that "it was about time prisoner was in gaol....Women of her class must be taught that they had no right to rob men whom they spoke to in the streets."106 Despite this, Williams received a sentence of only six months. In fact, around 90 percent of convicted female pickpockets received sentences of two years or less, even though larceny from the person was liable to sentences of up to ten years. ${ }^{107}$ 
By contrast, only around 67 percent of men convicted of burglary or breaking and entering received terms of two years or less (see Table 6). While there was little trouble in convicting male burglars, concerns about the crime's prevalence meant judges did regularly inflict sentences with the declared intention of enacting exemplary justice. ${ }^{108}$ Across the period, even youthful offenders were subject to comparatively lengthy sentences on the grounds that burglars were the "most dangerous of thieves." ${ }^{109}$ Male burglars were also likely to receive additional punishments, such as whippings or periods of solitary confinement. The excessive period King spent in solitary, thanks to infractions of prison discipline that compounded the sentences he received at trial, eventually led to an intervention in his prison treatment by the Premier himself after fears were expressed for King's mental health. ${ }^{110}$

\begin{tabular}{|c|c|c|}
\hline \multicolumn{2}{|c|}{ Table 6. Sentences received by convicted male burglars and female pickpockets } \\
\hline $\begin{array}{c}\text { Sentence } \\
\begin{array}{c}\text { Nominal imprisonment or } \\
\text { discharged }\end{array}\end{array}$ & Burglary & $1(<1 \%)$ \\
\hline $\begin{array}{c}\text { Bond, suspended sentence or } \\
\text { fine }\end{array}$ & $23(6 \%)$ & $3(1 \%)$ \\
\hline Reformatory & $5(1 \%)$ & 0 \\
\hline 6 months or under & $78(19 \%)$ & $64(30 \%)$ \\
\hline 6-12 months & $84(20 \%)$ & $75(35 \%)$ \\
\hline $1-2$ years & $89(21 \%)$ & $49(23 \%)$ \\
\hline 2-3 years & $51(12 \%)$ & $9(4 \%)$ \\
\hline $3-5$ years & $35(8 \%)$ & $7(3 \%)$ \\
\hline 5-7 years & $12(3 \%)$ & 0 \\
\hline 7-10 years & $2(<1 \%)$ & 0 \\
\hline Over 10 years & $1(<1 \%)$ & $4(2 \%)$ \\
\hline Indeterminate sentence & $34(8 \%)$ & 0 \\
\hline Death & $3(<1 \%)$ & 213 \\
\hline Total & 417 & \\
\hline
\end{tabular}

As views on the purpose of punishment began to change at the turn of the century, ${ }^{111}$ the problem of how to deal with thieves was central to discussion of sentencing reform. Both burglary and pickpocketing were rhetorically linked to proposals for the introduction of indeterminate sentencing for repeat offenders, perhaps suggesting that complacency about 
pickpocketing was receding. As early as 1889, a judge sentencing two women to three years' hard labor was described expressing

regret that the Legislature had not provided a place where habitual criminals could be kept for a long term of years, as, he said, no sooner were they out of gaol for one offence than they committed another, which entailed trouble to the police and the expense of a trial to the state. ${ }^{12}$

However, newspapers later reported that it was the "serious outbreak of crime in the shape of burglary" that brought the question of indeterminate sentences into prominence in the early 1900s. ${ }^{113}$ In 1906 the Age cited the large proportion of burglaries that went unsolved as evidence of "the necessity of checking the profession of crime by means of the indeterminate sentence."114 The paper added that pickpocketing went "unpunished still more frequently," thanks to both a high rate of undetected offenders and a high rate of acquittals. ${ }^{115}$ The following year the Victorian Parliament passed the Indeterminate Sentences Act, which allowed for the indefinite detention of habitual criminals. ${ }^{116}$

The gender disparity continued in the deployment of indeterminate sentencing provisions. Of women convicted of larceny from the person following the 1907 reform, 10.5 percent were given indeterminate sentences, compared to 19.2 percent of men convicted for burglary. The low rate of larcenous women given indeterminate sentences was simply reflective of the low rate of women given indeterminate sentences generally. A different idea of the seriousness with which female pickpocketing was regarded is demonstrated by the figures given in the reports of the Indeterminate Sentences Board. In 1915, four out of the fifteen women serving indeterminate sentences were doing so for larceny from the person. Proportionally, this figure was not so far removed from the 52 out of 160 men who were serving indeterminate sentences for burglary or breaking and entering. ${ }^{117}$

Walker was declared a habitual criminal as part of her sentence for robbing William Barrie in 1909. Undaunted, Walker's reply to the judge was: "You have given me a nice 
birthday present your Honor. Thank you." 118 Nevertheless, the sentence did have an effect on her. Walker's prison discharge in 1913 marks the end of her criminal record in Victoria. She moved to Sydney, where she was again convicted of stealing from the person in $1918 .{ }^{119}$ No further trace of her after that has been found.

King was declared a habitual criminal in 1908. Unlike Walker's glib response, King's reaction was far bleaker. ${ }^{120} \mathrm{He}$ continued to be a disruptive force in prison, undergoing additional trials in 1910 and 1911 for two separate incidents of stabbing a prison guard. Other inmates claimed King had said he would rather hang for murder than spend his life inside. ${ }^{121}$ In 1916, King was deported back to America. O’Donnell later claimed that authorities knew that the captain of the ship King sailed on had threatened to kill King if he misbehaved. ${ }^{122}$ Newspapers at the time simply reported that King became ill during the voyage and was buried at sea. ${ }^{123}$

\section{Conclusion}

Lily Walker was far from the ideal model of femininity that usually inspired leniency towards women in the legal system; yet it was the male victims of Walker and others like her that often emerged as subjects of community suspicion and disdain at trial. Meanwhile, William King — although never tried for a sexual offense — was positioned as a sexually threatening, nightmarish figure: an embodiment of more general anxieties burglary raised about the potential sexual victimization of women. In addition to what Walker and King's stories reveal about historical victimology, their experiences illuminate divergent trends between offender groups in conviction patterns, types of defense strategies employed and 
rates of legal representation, as well as the changing punitive responses towards these offenses.

Ironically, the introduction of the Indeterminate Sentences Act occurred just as female pickpocketing was declining, probably as a result of growing police scrutiny over prostitution. The dominance of burglary among male defendants, however, increased across the twentieth century. These trends appear to have simply reinforced existing victimization narratives. Female pickpocketing became associated not with a criminal class but with a smaller, more clandestine underworld that was even more clearly demarcated from respectable haunts. ${ }^{124}$ Meanwhile, the widespread nature of burglary, and the increased violence associated with it in the interwar period, meant it only became more threatening. ${ }^{125}$

The greater success attendant upon the prosecution of male burglary than female pickpocketing was connected not only to defendant gender, but also to the sexual scripts and cultural tropes constructed around victimization. The contempt engendered by male victims of female pickpocketing, and the terror inspired by burglary's threat of sexual violence, demonstrates the valuable insights that the study of property crime can offer to gender analysis, as well as to the history of emotions and sexuality. Offering a different perspective than that provided by accounts of other crimes, the influence of these gendered narratives of victimization on juries further illuminates the way the policing of gender, class and sexuality operated in the courtroom.

\section{Endnotes}

\footnotetext{
${ }^{1}$ Age (Melbourne), 27 November 1885, 6.

${ }^{2}$ Clive Emsley, Crime and Society in England 1750-1900, 2nd ed. (London, 1996), 100.

${ }^{3}$ Argus (Melbourne), 13 June 1888, 9.

${ }^{4}$ Coburg Leader, 23 April 1898, 3.
} 
${ }^{5}$ Manon van der Heijden, "Women and Crime," in The Oxford Handbook of the History of Crime and Criminal Justice, edited by Paul Knepper and Anja Johansen (Oxford, 2016), 253.

${ }^{6}$ A small sample: Judith A. Allen, Sex and Secrets: Crimes Involving Australian Women since 1880 (Melbourne, 1990); Jill Bavin-Mizzi, Ravished: Sexual Violence in Victorian Australia (Sydney, 1995); Raelene Frances, Selling Sex: A Hidden History of Prostitution (Sydney, 2007); Nicola Goc, Women, Infanticide and the Press, 1822-1922: News Narratives in England and Australia (Burlington, 2013).

${ }^{7}$ Elaine S. Abelson, When Ladies Go a-Thieving: Middle-Class Shoplifters in the Victorian Department Store (New York, 1989); Patricia O'Brien, “The Kleptomania Diagnosis: Bourgeois Women and Theft in Late Nineteenth-Century France," Journal of Social History 17, no. 1 (1983): 65-77.

${ }^{8}$ Shani D'Cruze and Louise A. Jackson, Women, Crime and Justice in England since 1660 (Houndsmills, 2009), 30-46.

${ }^{9}$ Deirdre E. P. Palk, Gender, Crime and Discretion in the English Criminal Justice System 1780s to 1830s, PhD thesis, University of Leicester, 2001, 141.

${ }^{10}$ J. M. Beattie, Crime and the Courts in England 1660-1800 (Oxford, 1986), 163.

${ }^{11}$ Peter King, Crime and Law in England, 1750-1840: Remaking Justice from the Margins (Cambridge, 2006), 168-172.

12 Joanna Bourke, Rape: A History from 1860 to the Present Day (London: 2007).

${ }^{13}$ Martin J. Wiener, Men of Blood: Violence, Manliness, and Criminal Justice in Victorian England (Cambridge, 2004).

${ }^{14}$ van der Heijden, "Women and Crime," 253.

${ }^{15}$ Magaly Rodríguez García, "Ideas and practices of prostitution around the world," in The Oxford Handbook of the History of Crime and Criminal Justice, edited by Paul Knepper and Anja Johansen (Oxford, 2016), 138.

${ }^{16}$ Criminal Trial Brief Register I, 1855-1891, VPRS 3523, Public Records Office Victoria (hereafter PROV); Criminal Trial Brief Register II, 1892-1961, VPRS 3524, PROV.

${ }^{17}$ Mark Finnane, Andy Kaladelfos, Alana Piper, Yorick Smaal, Robyn Blewer and Lisa Durnian, The Prosecution Project Database https://prosecutionproject.griffith.edu.au, (version 1, 17 July 2016), accessed 30 October 2015.

${ }^{18}$ William M. Meier, Property Crime in London, 1850-Present (New York, 2011), 43.

${ }^{19}$ Eloise Moss, “'How I Had Liked This Villain! How I Had Admired Him!': A. J. Raffles and the Burglar as British Icon, 1898-1939," Journal of British Studies 53 (2014): 136-61.

${ }^{20}$ David George O'Donnell, "Reminiscences of a Victorian Detective," Gisborne Gazette, 20 March 1925, 8.

${ }^{21}$ Fiona Brookman, Christopher Mullins, Trevor Bennett and Richard Wright, "Gender, Motivation and the Accomplishment of Street Robbery in the United Kingdom," British Journal of Criminology 47 (2007): 862. 
${ }^{22}$ As evidenced in: R v Henry Bolton and Wife, Victorian Law Report 144 (1885): 776. See also: Palk, Gender, Crime and Discretion in the English Criminal Justice System 1780s to 1830s, 46.

${ }^{23}$ Argus (Melbourne), 18 December 1884, 6; Truth (Melbourne), 13 October 1906, 2; See also, Lucy Chesser, Parting With My Sex: Cross-dressing, inversion and Sexuality in Australian Cultural Life (Sydney, 2008).

${ }^{24}$ Beattie, Crime and the Courts in England 1660-1800, 180.

${ }^{25}$ Palk, Gender, Crime and Discretion in the English Criminal Justice System 1780s to 1830s, 133.

${ }^{26}$ J.J. Tobias, Urban Crime in Victorian England (New York, 1972), 92.

${ }^{27}$ Alana Jayne Piper, “Us Girls Won't Put One Another Away’: Relations Among Melbourne's prostitute pickpockets, 1860-1920," Women's History Review (advance access version published online 4 May 2017) 1-19.

${ }^{28}$ As evidenced in the comments of this former Melbourne police detective: David George O'Donnell, "Reminiscences of a Victorian Detective," Gisborne Gazette, 26 June 1925, 8. See also: Emsley, Crime and Society in England 1750-1900, 100.

${ }^{29}$ Larry Wolff, “"The Boys Are Pickpockets, and the Girl Is a Prostitute': Gender and Juvenile Criminality in Early Victorian England from 'Oliver Twist to London Labour'," New Literary History 27, no. 2 (1996): 227-49.

${ }^{30}$ Chris McConville, "From 'Criminal Class' to 'Underworld'," in The Outcasts of Melbourne: Essays in Social History, edited by Graeme Davison, David Dunstan and Chris McConville (Sydney, 1985), 71; Emsley, Crime and Society in England 1750-1900, 100.

${ }^{31}$ William Henry Manwaring, Notes from His Diaries, 1897, Papers, 1865-1897, MS13674, Box 15/9, State Library Victoria (hereafter SLV), 9-10.

32 David George O'Donnell, "Reminiscences of a Victorian Detective," Gisborne Gazette, 19 September 1924, 8.

${ }^{33}$ Finnane et al, The Prosecution Project Database.

${ }^{34}$ Leader (Melbourne), 13 February 1875, 21; Argus (Melbourne), 6 February 1890, 6; Age (Melbourne), 20 September 1861, 7.

${ }^{35}$ R v Margaret Ellen Pearce, Victorian Law Report 95 (1877): 125.

${ }^{36}$ Age (Melbourne), 4 December 1885, 7.

${ }^{37}$ Australasian (Melbourne), 19 July 1890, 40.

${ }^{38}$ Allen, Sex and Secrets, 31-32; Lucia Zedner, Women, Crime, and Custody in Victorian England (Oxford, 1991), 43.

${ }^{39}$ Age (Melbourne), 7 April 1905, 7.

${ }^{40}$ R v William King, letter to judge, 1911/77, VPRS 30/P0, Public Records Office Victoria (hereafter PROV). 
${ }^{41}$ Leader (Melbourne), 2 November 1861, 14.

${ }^{42}$ Piper, “"Us Girls Won’t Put One Another Away,” 8.

${ }^{43}$ J. M. Beattie, "The Criminality of Women in Eighteenth-Century England," Journal of Social History 8, no. 4 (1975): 80-116.

${ }^{44}$ van der Heijden, "Women and Crime," 254.

${ }^{45}$ Clive Emsley, Crime and Society in Twentieth-Century England (Harlow, 2011), 27.

${ }^{46}$ R v. Caroline Collison and Margaret Kerwin, 1895/221; R v. Mary Andrews, 1899/398, VPRS 30/P0, PROV.

${ }^{47}$ Eamonn Carrabine, Paul Iganski, Maggy Lee, Ken Plummer and Nigel South, Criminology: A Sociological Introduction (London, 2004), 117.

${ }^{48}$ Criminal Trial Brief Registers I and II, 1860-1920, VPRS 3523 and VPRS 3524, PROV.

${ }^{49}$ Prahran Telegraph, 18 May 1901, 3; Reporter (Box Hill), 3 November 1911, 8.

${ }^{50}$ Basia Spalek, Crime Victims: Theory, Policy and Practice (Houndmills, 2006), 34.

${ }^{51}$ Age (Melbourne), 30 June 1891, 6; Age (Melbourne), 10 February 1891, 6.

${ }^{52}$ Eloise Moss, "Burglary Insurance and the Culture of Fear in Britain, 1889-1939," The Historical Journal 54, no. 4 (2011): 1039-64.

${ }^{53}$ Hazel Croall, "Social Class, Social Exclusion, Victims and Crime," in Victims, Crime and Society, edited by Pamela Davies, Peter Francis and Chris Greer, (Los Angeles, 2007), 51.

${ }^{54}$ Beattie, "The Criminality of Women in Eighteenth-Century England," 90; Emsley, Crime and Society in England, 1750-1900, 80.

${ }^{55}$ R v Elizabeth Wilson and Margaret Dougan, 1915/555, VPRS 30/P0 Trial Briefs, PROV.

${ }^{56}$ Age (Melbourne), 19 November 1885, 5.

${ }^{57}$ R v Mary Bennett and Susan Caldwell, 1864/20; R v Mary Rangle, 1866/2; R v Sarah Scott and Elizabeth Gosling, 1866/13; R v Mary Ann Horne, 1866/4; R v Bridget Craig/4, 1867; R v Alice Smith, 1901/8, VPRS 30/P0 Trial Briefs, PROV.

${ }^{58}$ Mercury and Weekly Courier (Fitzroy), 22 September 1883, 3.

${ }^{59}$ Age (Melbourne), 9 March 1869, 3.

${ }^{60}$ J. B. Castieau, 17 February 1874, The diaries of John Buckley Castieau, MS 2218, National Library of Australia.

${ }^{61}$ Argus (Melbourne), 5 March 1902, 5.

${ }^{62}$ Age (Melbourne), 4 March 1885, 6; Age (Melbourne), 22 March 1905, 11; Argus

(Melbourne), 17 December 1908, 8.

${ }^{63}$ Age (Melbourne), 16 July 1875, 3. 
${ }^{64}$ Suresh Kanekar, Nirmala J. P. Pinto and Deepa Mazumdar, "Causal and Moral Responsibility of Victims of Rape and Robbery," Journal of Applied Social Psychology 15, no. 4 (1985): 622-37; Christiane Brems and Patricia Wagner, "Blame of Victim and Perpetrator in Rape Versus Theft," The Journal of Social Psychology 134, no. 3 (1994): 363 74; Steffen Bieneck and Barbara Krahé, "Blaming the Victim and Exonerating the Perpetrator in Cases of Rape and Robbery: Is There a Double Standard?" Journal of Interpersonal Violence 26 (2011): 1785-97.

${ }^{65}$ Age (Melbourne), 25 November 1908, 7.

${ }^{66}$ Ibid.

${ }^{67}$ Argus (Melbourne), 8 February 1909, 8.

${ }^{68}$ Age (Melbourne), 18 March 1909, 7.

${ }^{69}$ Age (Melbourne), 11 February 1909, 6.

70 Age (Melbourne), 18 March 1909, 7.

${ }^{71}$ Argus (Melbourne), 20 September 1871, 7.

${ }^{72}$ R v William Argall, 1901/308, VPRS 30, PROV.

${ }^{73}$ R v Thomas Sanders and John Johnson, 1861/3, VPRS 30/P0, PROV; R v James Jackson, 1872, VPRS 264/P0, PROV.

${ }^{74}$ Bavin-Mizzi, Ravished, 154.

75 Argus (Melbourne), 30 June 1911, 7; Argus (Melbourne), 25 November 1891, 9; Age (Melbourne), 2 July 1901, 7.

${ }^{76}$ R v Francis Lyons and James Hayes, 1891/11; R v Joseph Williams, 1911/271, VPRS 30/P0, PROV.

${ }^{77}$ David George O'Donnell, "Reminiscences of a Victorian Detective," Gisborne Gazette, 20 March 1925, 8.

${ }^{78}$ Argus (Melbourne), 16 May 1900, 4; R v William King, 1900/249, VPRS 30/P0, PROV.

${ }^{79}$ Argus (Melbourne), 11 November 1909, 6.

${ }^{80}$ Argus (Melbourne), 4 August 1908, 5; Argus (Melbourne), 19 August 1908, 9

${ }^{81}$ David George O’Donnell, "Reminiscences of a Victorian Detective," Gisborne Gazette, 20 March 1925, 8.

${ }^{82}$ Cassandra Pybus, Black Founders: The Unknown Story of Australia's First Black Settlers (Sydney, 2006), 2-3.

${ }^{83}$ Mark Finnane and Andy Kaladelfos, "Race and Justice in an Australian Court: Prosecuting Homicide in Western Australia, 1830-1954," Australian Historical Studies 47, no. 3 (2016): 449.

${ }^{84}$ Age (Melbourne), 29 January 1886, 7. 
85 Argus (Melbourne), 30 June 1911, 7.

${ }^{86}$ Police News (Melbourne), 22 April 1876, 1.

${ }^{87}$ Police News (Melbourne), 2 June 1877, 1. (See figure 1)

${ }^{88}$ R v. Margaret Welsh, 1860/3; R v. Louisa King and John McDonald, 1865/22; R v. Ada Capewell, 1895/301; R v. Kate Melville, 1902/14, VPRS 30/P0, PROV.

89 Tony Henderson, Disorderly Women in Eighteenth-Century London: Prostitution and Control in the Metropolis, 1730-1830 (London, 1999), 36.

90 Jody Miller, "Up It Up: Gender and the Accomplishment of Street Robbery," Criminology 36, no. 1 (1998): 46.

${ }^{91}$ Argus (Melbourne), 15 February 1889, 9; Argus (Melbourne), 7 February 1890, 7.

${ }^{92}$ Argus (Melbourne), 30 March 1887, 5

93 Argus (Melbourne), 23 October 1891, 10.

${ }^{94}$ Argus (Melbourne), 22 June 1901, 15; Argus (Melbourne), 12 February 1921, 17; Age

(Melbourne), 28 April 1921, 9.

${ }^{95}$ Argus (Melbourne), 5 June 1900, 8

${ }^{96}$ Argus (Melbourne), 20 August 1908, 7.

${ }^{97}$ George Edwards, Papers 1870-1930, MS 13664, Box 4033, SLV.

${ }^{98}$ John Adrian Lynch, Legal Aid and the Legal Profession in Victoria 1841-1995, PhD thesis, La Trobe University, 1996, 3.

${ }^{99}$ Frances, Selling Sex, 166; "Report from the Select Committee Upon a Bill for the Prevention of Contagious Diseases," Victoria Parliamentary Papers (hereafter VPP) (1878): 12; "Report of the Inspector-General for the Year 1890," VPP (1891): 5.

${ }^{100}$ Age (Melbourne), 29 January 1886, 7.

101 Argus (Melbourne), 2 June 1900, 6.

102 Leader (Melbourne), 6 April 1861, 6; Argus (Melbourne), 16 March 1871, 7; Age (Melbourne), 3 August 1881, 1.

${ }^{103}$ Cerian Charlotte Griffiths, “The Prisoners' Counsel Act 1836: Doctrine, Advocacy and the Criminal Trial," Law, Crime and History 4, no. 2 (2014): 28-47.

${ }^{104}$ Mount Alexander Mail, 13 January 1903, 2.

105 Argus (Melbourne), 10 July 1903, 3.

${ }^{106}$ Age (Melbourne), 5 November 1909, 10.

107 Crimes Act 1890 (Vic) s 109.

108 Age (Melbourne), 22 June 1911, 5. 
109 Argus (Melbourne), 4 June 1881, 9; Argus (Melbourne), 11 October 1921, 11.

110 Argus (Melbourne), 16 February 1909, 5; Argus (Melbourne), 24 May 1909, 6.

${ }^{111}$ Mark Finnane, Punishment in Australian Society (Melbourne, 1997), 65.

112 Argus (Melbourne), 8 February 1889, 4.

${ }^{113}$ Examiner (Launceston), 8 July 1907, 4.

114 Age (Melbourne), 18 July 1905, 4.

115 Age (Melbourne), 18 July 1905, 4.

${ }^{116}$ Indeterminate Sentences Act 1907 (Vic) s 4; Finnane, Punishment in Australian Society, 78-79.

117 “Annual Report of the Indeterminate Sentences Board for the year ended $30^{\text {th }}$ June 1915 ," $\operatorname{VPP}$ (1915): 12-15.

118 Age (Melbourne), 30 March 1909, 8.

${ }^{119}$ New South Wales Police Gazette, 6 March 1918, 110.

${ }^{120}$ Argus (Melbourne), 20 August 1908, 7

${ }^{121}$ R v William King, 1911/77, VPRS 30/P0, PROV.

122 David George O'Donnell, "Reminiscences of a Victorian Detective," Gisborne Gazette, 20 March 1925, 8.

${ }^{123}$ Argus (Melbourne), 26 May 1916, 8.

${ }^{124}$ McConville, "From 'Criminal Class' to 'Underworld'," 90.

${ }^{125}$ Emsley, Crime and Society in Twentieth-Century England, 24. 